Research, part of a Special Feature on Realizing Water Transitions: The Role of Policy Entrepreneurs in Water Policy Change

\title{
Water Management in Spain: the Role of Policy Entrepreneurs in Shaping Change
}

\author{
$\underline{\text { Nuria Font }}^{1}$ and $\underline{\text { Joan Subirats }}^{1}$
}

\begin{abstract}
The role played by policy entrepreneurs in preparing, initiating, and implementing water policy change in Spain over the last two decades is examined in an effort to understand how transitions in water management occur. The main questions considered are whether policy entrepreneurs can influence water policy change, and which strategies they actually adopt to promote change. John Kingdon's multiple streams framework was used to assess the ways in which policy entrepreneurs succeed in challenging the dominant agenda, mobilizing alternative policy ideas, and making use of multiple venues for initiating policy change. The data set comprises secondary documentation and interviews with state and non-state actors involved in Spanish water management. The main findings are that policy entrepreneurs from certain social, scientific, and political organizations have indeed played a central role in fracturing the traditional and long-standing approach and decision making process to water management as well as in opening new avenues for policy change. The main implication is that accounts of water management transitions should place greater emphasis on the role of agency in bringing about policy change.
\end{abstract}

Key Words: policy entrepreneurs; Spain; transitions; water management

\section{INTRODUCTION}

Over the last 20 years, water management policy in Spain has shown signs of a gradual transition. Traditionally, Spain's problem-solving approach to water policy has consisted of the regulation of the water supply by means of state-subsidized construction of large-scale infrastructure. While not completely abandoned, the supply-based approach to water policy has taken tentative steps towards a concept based more on sustainability of the resource. Significantly enough, the National Water Plan adopted by the Popular Party administration in 2001, which heavily rested on traditional management and decision making principles and actors, was revoked three months after the Socialist Party won the national elections in March 2004. The newly elected government adopted the Actions for Water Use and Management program (AGUA) shortly afterwards, introducing desalinization as a policy aim intended as part of a shift to alternative supply-based regulation methods (Ministerio de Medio Ambiente 2005). The program was expected to represent a fundamental shift in water management policy (Downward and Taylor 2007), although the outlooks for change are uncertain.

The literature provides several perspectives on cultural, historical, or agent-based approaches to creating changes in water policy. From a cultural perspective, Tàbara and Ilhan (2008) argue that the role played by the production and use of cultural constructs, including world views, beliefs, and values, has brought about transition in water management policies and power structures in Spain. For the authors, the so-called New Water Culture movement (New Water Culture Foundation 2010) exemplifies such cultural triggers in adaptation toward sustainability. This interpretation would indeed apply to a change in the institutionalized policy image, as suggested by Baumgartner and Jones (2002), who propose that opponents to the dominant policy frameworks develop new ideas that challenge the status quo. While such interpretation provides interesting insights on the transformation of ideas underlying policy changes, it draws less 
attention to the long-term processes that actually drive change and that appear to be of crucial importance in lengthy and incremental transitions.

Historical institutionalism (North 1990, Thelen 1999, Pierson 2000) might account for why some policies become very stable. This approach emphasizes the concept of path dependency by which previous steps in a given policy direction are seen to guide future movement in the same direction. Policies are thus self-reinforcing as a result of an increasing returns process (Pierson 2000), which means that the costs of changing the policy direction become progressively higher. Policy inertia is perhaps one of the overall trends most inherent to water policies, which tend to perpetuate their constituent trends. Therefore, one core premise of path-development processes is that policies change incrementally. Change may occur in either the substantive content of policy or in the dominant governance paradigm. A window can open for a change in the direction of policy with the advent of a critical juncture or a fundamental crisis. In order to account for both policy change and policy stability, historical institutionalism suggests adopting a long-term perspective. This is particularly appropriate when studying water policy, as it is an area of public initiatives based on long-standing core policy beliefs and practices, where changes, when they take place, are of an incremental nature. Costejà et al. (2004) and Bukowski (2007), in their analysis of water policy change in Spain, share a methodological assumption of the need to take a long-term perspective. This article too, assumes that trends toward policy and institutional inertia are intrinsic to water policy, making it necessary to understand indicators of change in a historical context and as part of a cumulative succession of events.

However, the focus on the historical path is not sufficient to account for policy change, and needs to be complemented by a review of actors' intentionality. According to Pierson (2000), historical institutionalism is not at odds with this agent based approach. Policy and institutional inertia may restrict or even lock in the course of possible actions, but it does allow room for strategic behavior. In other words, action matters. Actors may be able to mobilize material and ideational resources strategically in order to change the course of a policy. In this sense, Bukowski (2007), in analyzing Spanish water policy, adopts an advocacy coalition framework and identifies two coalitions - one of environmentalists, the other of marketizers sharing core beliefs, whose interplay accounts for policy continuity and change. Possibly of greater interest are the modes in which individuals and groups develop entrepreneurial activities, including building such coalitions, raising alternative policy images, and exploiting multiple venues in order to prompt policy change (Huitema and Meijerink 2010).

In line with the theoretical approach of this special feature, this paper explores the role of policy entrepreneurs in prompting policy change (Huitema and Meijerink 2010). We posit that Kingdon's (1995) multiple streams model may provide analytical tools to better understand how alternative ideas on water policy have been relatively accepted by policy-makers. According to Kingdon, policy formation and change results from the coupling of three relatively independent streams: problem streams, policy streams, and politics streams. When these three streams couple, a policy window opens, possibly resulting in policy change. This article focuses on the role played by policy entrepreneurs as pro-active agents of change throughout a twodecade transition period in Spain. Policy entrepreneurs in this case include a coalition of social, scientific and political organizations. The strategies they employ consist mostly of developing and selling alternative policy ideas, building coalitions, and exploiting venues, particularly in the European Union (EU), to challenge the dominant agenda and promote alternative approaches to water management. This article employs a qualitative design based on document analysis and semistructured interviews conducted in 2005-2006 with civil servants, industry representatives, and social groups involved in Spanish water management. The paper is divided in three sections. The first section presents a three-stage model of water policy transitions based on the behavior of policy entrepreneurs and their impact on policy. The second section explores the resources mobilized by policy entrepreneurs and the type of strategies they employ to bring about policy change. The third section contains a discussion on the theoretical implications of the study, while the Conclusions section assesses the completeness of the transition and suggests some outlooks for the future. 


\section{WATER MANAGEMENT IN TRANSITION: A THREE-STAGE MODEL}

\begin{abstract}
Water management in Spain was institutionalized in the late nineteenth century by the enactment of the first and second water acts of 1866 and 1879, respectively, which were later modified by the provisions on water contained in the Civil Code in 1889. This legal framework lacked a fully developed policy dimension and gave the state administration few powers (Costejà et al. 2004). This situation started to change at the end of the nineteenth century partly because of the influential intellectual "regeneracionist" movement's promotion of the idea of state investment in hydraulic infrastructures as a national strategy for modernizing the country (Costejà et al. 2004). A few decades later, state regulation of water resources, mostly for irrigation, was heavily used by the Franco regime.
\end{abstract}

The advent of democracy in the 1970s completely transformed the political system and opened windows for a transformation of the water management regime. The adoption of the Spanish Constitution in 1978, in particular, helped bring about change in water management by changing the larger institutional context in which it was embedded. The creation of a decentralized political structure, the so-called State of Autonomous Communities, led to the distribution of water management powers between national and regional governments. The former hold exclusive powers over the declaration of continental waters, covering both surface and ground renewable waters as public domain, as well as state control over access. The national administration is also responsible for legislation, planning, and granting of government concessions and authorization when waters flow through more than one autonomous community; the projection of hydraulic works when such are declared to be of public interest or to affect more than one autonomous community; and environmental protection legislation and planning. The Ministry of the Environment, created in 1996, has responsibility for water policy. It is responsible for the production, supervision, and review of the National Water Plan, the definition of systematic criteria for the review of river basin hydrological plans and the coordination of sectoral or regional plans affecting hydrological planning. Hydrographical confederations are the main water management bodies that, in the case of inter-regional river basins, are attached to the Ministry of the Environment. Water also occupies a central position in the Autonomous Communities, especially since some of their basic laws that established the balance of power between them and the State have recently been revised. In brief, regional administrations are responsible for managing intra-regional river basins, specifically for the projection, construction, and exploitation of hydraulic resources, channels, and irrigation infrastructure of regional interest; legislation and management of mineral waters, thermal springs, shell fishing, aquaculture, and fluvial fishing: and in some autonomous communities, the introduction of legislation on environmental protection. Most importantly, it is the regional governments, not the national government, that have the power to authorize intra-regional water transfers. However, there are cross-regional variations as not all autonomous communities have the same type and level of institutional development with regards to water management. In addition to the national and regional administrations, local administrations, including about 8000 municipalities, are responsible for water supply and sanitation.

Together with the erosion of powers entailed in the decentralization of the national water administration, sectoral legislation on water has modified the parameters of policy. The Water Act (29/1985) placed an emphasis on state intervention by extending the idea of the public domain and focusing on planning. It also moved towards a more integrated approach in its conceptualization of water as a unitary resource and by introducing the concepts of sanitation, water resource quality preservation, civil protection, environmental values, and territorial planning (Costejà et al. 2004). The new legal framework attempted to adapt water policy to a political, socio-economic, and technological context that had been thoroughly transformed over the previous decades in terms of the increase in the number of uses and users.

Following a mandate of the 1985 Water Act, the government presented a draft version of the National Water Plan in 1993. The plan perpetuated the traditional hydraulic paradigm consisting of state regulation of water resources through the construction of large-scale infrastructure, namely dams and inter-basin transfers, with the ultimate objective of supplying water for everybody at zero cost whenever and wherever needed (Saurí and del Moral 2001). However, the attempts by the government to adopt a water planning instrument, with successive drafts released between 1993 and 
1995, were unsuccessful. The projected plan was heavily criticized mainly by the donor regions' principally Aragon - environmentalists and practitioners. This marked a turning point because for the first time a water plan provoked enough negative reaction to make the government withdraw it. Thus, it was at the beginning of the 1990s when the first signs of transition were detected.

In the analysis of water management over the last two decades, three different stages can be identified. These stages correspond to the terms in office of the three national single-party governments since the early 1990s (Table 1). The first stage, emerging protest, covers the minority government of the Socialist Party between 1993 and 1996. During this period, protest by general public actors and practitioners prevented the government from adopting a planning instrument that promoted the construction of huge water infrastructure. The second stage, polarization, includes two Popular Party governments during the periods 1996-2000 (minority government) and 2000-2004 (majority government). During the first minority government, the executive successfully reformed the existing legal framework on water policy. Yet, the government faced large-scale protests against the philosophy and content of the 2001 National Water Plan during the subsequent majority government. Finally, the third stage, symptoms of change, started with the change of government following the national elections of 2004. During the period of the third stage, the Socialist Party government envisioned partially abandoning the traditional water development approach and defining alternative supply mode types of intervention mostly limited to the construction of desalinization plants. As noted, Spain's successive stages of transition are marked by changes of government. This does not mean, however, that change in the nation's water transition can be accounted for in terms of party politics. While the dynamics of government and opposition must not be downplayed, they have not been the driving force of change but rather have contributed to open windows of opportunity for policy entrepreneurs to act.

\section{Stage one (1993-1996): emerging protest}

Following the 1985 Water Act mandate, the Ministry of Public Works, Transport and Environment in 1993 developed a project ahead of the National Water Plan. The so-called Plan Borrell, named informally after the minister, perpetuated the traditional problem-solving approach to water scarcity. Based on the territorial solidarity principle, it argued that Spain had enough supplies of water to solve both the unequal geographic distribution of resources and the periodic recurrence of severe droughts (Saurí and Del Moral 2001). It aimed to satisfy the increasing demand for water and correct territorial imbalance through the construction of about 150 dams. After successive drafts and intense public debate, the plan was defeated in 1995 both in Congress, which made the adoption of a plan dependent on the production of a National Irrigation Plan, and in the Senate, which added the condition that each of the river basin plans should be presented before the plan could be adopted (Bakker 2002). Furthermore, the National Water Council also rejected the government's plan and submitted an alternative proposal calling for greater efficiency and rationality (Saurí and Del Moral 2001).

The underlying factor leading to the 1995 defeat of the National Water Plan was possibly the weak position of the minority Socialist Party government during the turbulent 1993-1996 legislature. This political situation stimulated the growing plurality of conflicting interests surrounding water management. On the one hand, the plan was welcomed by agricultural associations and the regions affected by water restrictions, which saw it as a solution to the water scarcity problem. On the other hand, the traditional consensus that had dominated water policy was broken by alternative definitions of the policy problem that were promoted by different types of actors, including economists, environmentalists, and the donor regions' actors. Not surprisingly, by invoking the principles of efficiency and conservation, economists and environmentalists formed strategic alliances in favor of a demand-led water policy over the traditional supply-based engineering approach (Bakker 2002). With a different perspective, the donor regions rejected the idea that water was a national asset and argued that water transfers would enhance economic activities in some Mediterranean regions, like Murcia, to the detriment of the more 
Table 1. Three-stage model in water policy transition.

\begin{tabular}{|c|c|c|c|}
\hline & $\begin{array}{l}\text { Stage } 1 \\
1993-1996\end{array}$ & $\begin{array}{l}\text { Stage } 2 \\
1996-2004\end{array}$ & $\begin{array}{l}\text { Stage } 3 \\
2004 \text { onwards }\end{array}$ \\
\hline & Emerging protest & Polarization & Symptoms of change \\
\hline Policy discourse & $\begin{array}{l}\text { Economic development and } \\
\text { modernization } \\
\text { Territorial and social solidarity }\end{array}$ & $\begin{array}{l}\text { Efficiency } \\
\text { Economic development } \\
\text { Territorial solidarity }\end{array}$ & $\begin{array}{l}\text { Sustainability } \\
\text { Rational use of water }\end{array}$ \\
\hline Policy approach & Supply-based & Market and supply-based & $\begin{array}{l}\text { Alternative regulation of water } \\
\text { supply }\end{array}$ \\
\hline Main policy output & $\begin{array}{l}1993-1995 \\
\text { Draft Project of National Water } \\
\text { Plan }\end{array}$ & $\begin{array}{l}2001 \\
\text { National Water Plan }\end{array}$ & $\begin{array}{l}2004 \\
\text { Suppression of the Ebro } \\
\text { transfers } \\
\text { AGUA program } \dagger \\
\text { WFD adaptation } \ddagger\end{array}$ \\
\hline $\begin{array}{l}\text { Main policy } \\
\text { interventions }\end{array}$ & $\begin{array}{l}\text { Large hydrological } \\
\text { infrastructures: } \\
\text { inter-basin transfers and about } \\
150 \text { dams }\end{array}$ & $\begin{array}{l}\text { Large hydrological } \\
\text { infrastructures: } \\
\text { inter-basin transfers } \\
\text { (Ebro) and about } 120 \text { dams }\end{array}$ & $\begin{array}{l}\text { Planning of } 105 \text { interventions } \\
\text { including desalinization plants }\end{array}$ \\
\hline Policy environment & $\begin{array}{l}\text { Protest at the traditional supply } \\
\text { approach }\end{array}$ & $\begin{array}{l}\text { Market efficiency accepted } \\
\text { but protest at the traditional } \\
\text { supply approach }\end{array}$ & $\begin{array}{l}\text { Alternative supply approach } \\
\text { partly accepted }\end{array}$ \\
\hline
\end{tabular}

$\dagger$ Actions for Water Use and Management program

\$ Water Framework Directive

depressed ones, namely Aragon (Saurí and Del Moral 2001). In this respect, Aragon was the first region to break with the traditional idea of territorial justice. In fact, all political forces in the region attained the so-called "Aragon Water Pact" in 1992 by virtue of which the region would not consent to transfers from the Ebro River while regional needs were not satisfied (Fig. 1). In addition, unrest crossed national frontiers. Portuguese opposition to water diversions from Spanish-Portuguese rivers added a new front of dissent.

\section{Stage two (1996-2004): polarization}

Following the failure of the projected 1993 plan, subsequent reforms to water policy were conducted in the late 1990s. The Popular Party government, newly elected in 1996, reformed the 1985 Water Act in 1999 by means of Act 46/99, which opened the door to the adoption of the National Water Plan through Act 10/2001. The national government, which was critical of the previous government's inability to define a national strategy to cope with the drought problem, urged that water policy strategy combine market efficiency and supplybased principles. As regards the former, the government created water banks and several public 
Fig. 1. Spain and its main rivers.

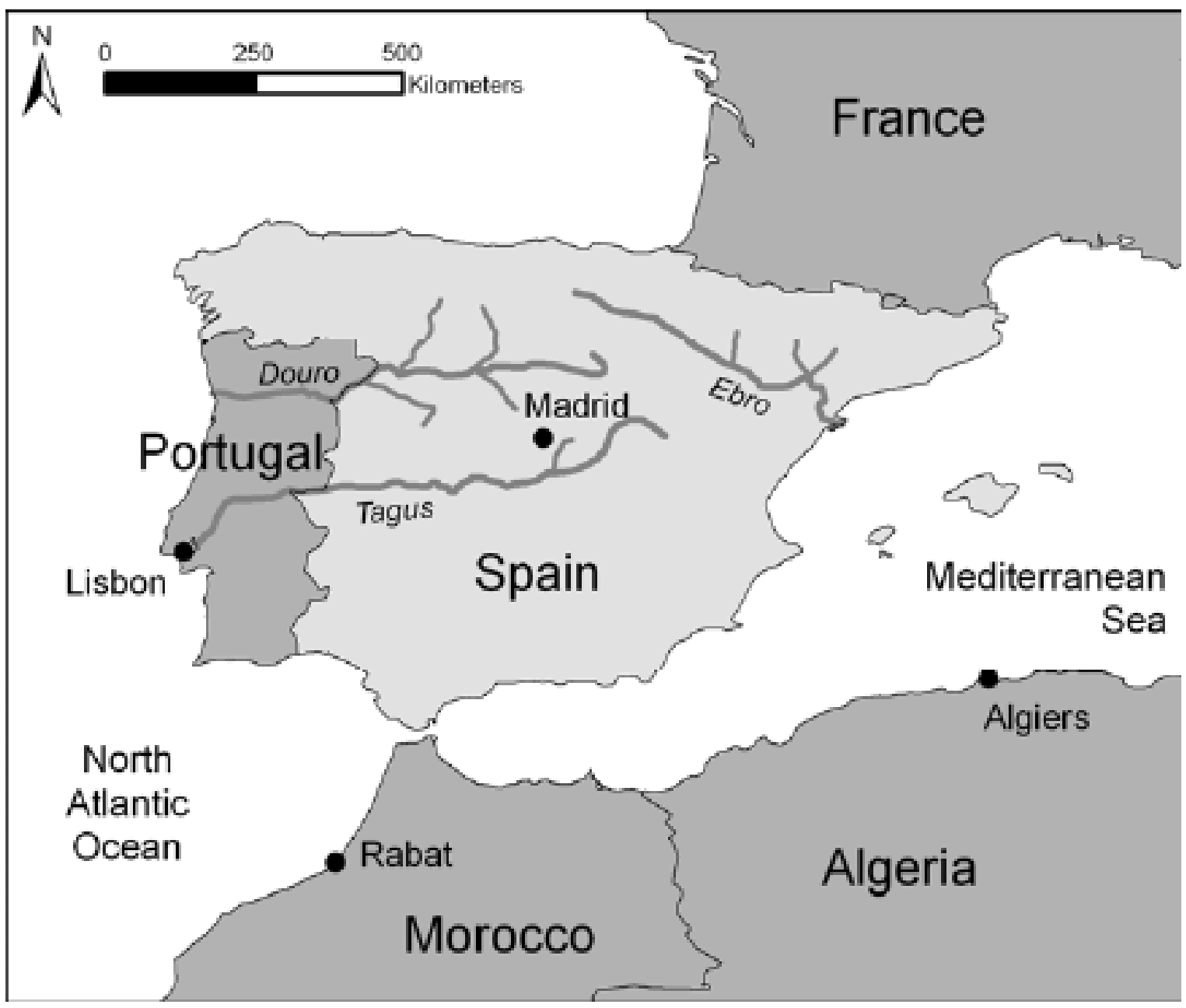

corporations known as "Sociedades Estatales." Water banks for the exchange of use rights aimed to introduce new efficiency parameters by making the water concession regime more flexible. This was seen in the creation of centres for the exchange of use rights for further cession to other users. Sociedades Estatales in turn are public-private partnerships designed to finance the most profitable hydraulic infrastructure projects, with those less profitable remaining in the hands of the state. As Bakker (2002) points out, the creation of Sociedades Estatales does not imply the abandonment of water policy as an instrument of the state, but represents a restructuring of funding mechanisms that would allow the state to seek private capital for profitable projects and EU funding for projects that are eligible under different criteria.

The Spanish government promoted the National Water Plan, which was adopted by parliament once the National Water Council had expressed its support. The plan contained two main aspects. First, it promoted the construction of large-scale hydraulic infrastructures that would transfer water from the surplus to the deficit river basins. By doing so, it aimed to satisfy the increasing demand for water that was arising from the combination of cyclical climate droughts with increased demand for water due to industrial, tourism, and urban development in the southeastern regions over the previous 
decade. The key project contained in the plan involved the transfer of $1050 \mathrm{hm}^{3}$ of water from the Ebro River, a central provider of the Spanish hydrological system, south along the Mediterranean coast to the Júcar, Segura, and South Almería basins and north to the internal basins of Catalonia. It also included the construction of about 120 water dams and river channels in Spanish territory.

The national government's strategy on water policy provoked mixed reactions. On the one hand, environmentalists and the neoliberal sectors welcomed the adoption of more flexible management instruments (Bukowski 2007). On the other hand, the National Water Plan was widely criticized by social, territorial, and political actors. Significantly enough, a wide range of social organizations, the scientific community, certain political parties, and some regional governments mobilized a wide range of political and cognitive resources to influence public opinion and exercise pressure on the national government to suppress the plan. However, in spite of intense protest against the National Water Plan, the national government, counting on a large majority in Parliament as well as support from some autonomous communities, maintained its position. Protest intensified and extended as a result. In other words, the plan generated an adverse response from large parts of society, which became engaged in intense informational campaigns, and mobilized scientific knowledge, formulated alternative solutions, and increased pressure on the government.

\section{Stage three (2004 onwards): symptoms of change}

The change of government in March 2004 generated a political opportunity for actors who were protesting against the construction of large water infrastructure. Shortly after being elected, the Socialist Party government, fulfilling an electoral promise, modified the 2001 National Water Plan, which included cancelling the Ebro River transfer and then quickly adopting the AGUA program (2004-2008) under the leadership of the Minister for the Environment, Cristina Narbona. By doing so, it took a step towards abandoning the traditional supply-based approach to water policy and several steps towards redefining the type of supply instruments. The AGUA program included more than 100 initiatives, namely the construction of water desalinization plants and the creation of public water banks. The program also included proposals for alternative methods of regulating water supply, but it barely regulated water demand, although it included this measure as an option. Partly to address this, the Ministry of the Environment launched a voluntary process of assessing the environmental sustainability of the urgent initiatives contained in the AGUA program for the Mediterranean basins. The document presented by the government received mixed reactions from the environmental community. Environmental groups, namely Greenpeace and World Wildlife Fund for Nature (WWF)-Spain, welcomed the assessment's inclusion of the "water restriction" option following the consultation process launched by the Ministry of the Environment. However, they objected to the fact that the document excluded from consideration some of the projects in the AGUA program in which the water restriction option was not recommended because of the strong public criticism it would create. These organizations also criticized the program for being based on the consumption of water and energy resources (WWF-Spain 2007).

In addition to constructing desalinization plants, the Ministry planned to create a public water bank in each hydrographical basin, which would allow historical water resources to be re-allocated according to criteria of equity, efficiency, and sustainability (Ministerio de Medio Ambiente, Programa AGUA, http://www.mma.es/secciones/agua/ pdf/programa.pdf). In October 2004, the government approved the implementation of centres of exchange of water rights at the Segura, Júcar, and Guadiana river basins. Environmental groups reacted positively to the creation of such a policy instrument by considering that it might hamper the impact of drought, but as WWF-Spain relates, they rejected the implementation of the banks in those river basins with long-standing problems caused by illegal wells and markets (Di Stefano and Schmidt 2005).

The new orientation of water management launched by the government in 2004 was partly stimulated by the approach of the Water Framework Directive (WFD). Inspired by the WFD, Minister Narbona, who was in office until 2008, advocated for water saving, efficiency, and "user pays" principles as contained in the WFD (Weyndling 2009). More specifically, she firmly advocated for the desalinization solution. The adaptation to the WFD, however, has been more prominent in Catalonia than in other regions or even in the Spanish context itself. Most participatory initiatives have been 
located in Catalonia, although other regions, for instance Navarra and Aragón, have also launched participation processes (Espluga and Subirats 2007). In some cases, those experiences have remained in a merely deliberation phase, while in other cases agreements have been reached and specific decisions have been made (Espluga and Subirats 2007). Significantly enough, the Catalan Water Agency has launched a broad process of participation and consultation and has further designed a water management strategy that prioritizes the improvement of water quality and the control of water demand (Esteban and Prat 2006).

Overall, despite symptoms of policy change, the national government's commitment to alternative schemes of regulating water supply has recently been reconsidered. Following the 2008 elections, which renewed the Socialist mandate, the Ministry of the Environment was integrated into the Ministry of Agriculture, which had traditionally advocated for a conventional supply-side approach to water management. The dismissal of Narbona and the appointment of former Minister of Agriculture, Elena Espinosa, as its new chief, led to inter-basin water transfers being included on the agenda. In the meantime, while some desalinization plants have been constructed along the Mediterranean basin over the last years, the desalinization alternative has lost its momentum for reasons of economic unfeasibility.

\section{POLICY ENTREPRENEURS OF WATER TRANSITIONS}

The first signs of crisis in the traditional model of water management appeared in the early 1990s. Intense public debate led to the involvement of experts and academics, environmentalists, consumer groups, trade unions, and economists in a strategic alliance between free market economists and environmentalists that questioned the supply-led engineering approach of the traditional paradigm (Bukowski 2007). This alliance challenged the traditional policy image that was based on hydro technology for surface waters and which was predicated on the basis of ever-increasing demand for water. Launched in the midst of a severe drought, the debate also exacerbated the "water wars" between wet and dry regions. The lack of consensus on the National Water Plan prevented the project from being adopted in Parliament.
Alternative policy ideas that were raised by opponents to the traditional schemes gradually gained room in the political debate and were included on the public agenda. The incipient mobilization of policy entrepreneurs who opposed the institutionalized policy image in the early 1990s was the seed of a large-scale movement in the following years. During the second stage of the transition, a wide range of social organizations, the scientific community, some regional administrations, and the Socialist Party developed active entrepreneurial activities and played a leading role in questioning the traditional approach.

Social organizations who opposed the traditional schemes included a wide range of stable and longstanding environmental groups, civic organizations, and territorially-based social movements. Those who played a clear entrepreneurial role included Greenpeace, WWF-Spain, SEO/BirdLife, and the Confederation of Organizations for Environmental Protection (CODA), which was in turn integrated into the New Water Culture Foundation, the Association of People Affected by Large Dams (COAGRET), and territorially-based social movements such as the Association for the Defense of the Ebro River. Beyond their differences, they shared common definitions of the water problem, adopted similar strategies, and pooled resources in order to maximize their efforts. Coalition building to enhance shared beliefs, ideas, and action has thus been a key aspect in their entrepreneurial strategies.

Social organizations were particularly active not only in producing ideas but also in selling them in order to instigate policy change. They based this strategy on the launch of joint campaigns against the 2001 National Water Plan, and had three main objectives: first, putting pressure on the government to withdraw the plan; second, and closely related to the first, creating a climate of opinion among Spanish society; and third, based on the production of technical studies, proposing policy alternatives. To fulfill these objectives, social organizations orchestrated ambitious campaigns that combined various types of actions. These groups made major efforts to fulfill the first of the three objectives. In this respect, the largest environmental organizations, including Greenpeace, WWF-Spain, and SEO/ BirdLife, as well as a wide range of social movements, including the Association for the Defense of the Ebro River, launched supra-national and national campaigns that condemned the social, economic, and environmental consequences of the 
plan. Further, these groups actively used multiple venues in an attempt to promote policy change. Key actions included the frequent provision of information and the lodging of complaints to the European Commission, and the presentation of petitions and questions to the European Parliament, all of which alleged that the National Water Plan, which was expected to be co-financed with EU funds, went against several EU environmental directives. Environmental groups considered that the large-scale infrastructure proposed in the Plan, in particular the Ebro diversion, had negative effects on Special Areas of Conservation and Special Protection Areas that constituted the Natura 2000 Network, and that it would have severe consequences for most water ecosystems. The same groups reported that the plan did not comply with the objectives contained in the WFD and that the government had produced merely partial assessments rather than a strategic environmental impact assessment of the plan. The Spanish government's adoption of both the WFD and the Strategic Impact Assessment Directive reinforced the arguments of the environmental groups and social movements in general, since no legal requirement to enforce the Directive existed when the plan was adopted. Apart from these actions, a variety of social organizations launched an intensive networking campaign in Brussels in order to sell ideas opposed to EU financing of the work that was projected in the National Water Plan.

The wide range of strategies employed by opponents to the National Hydrological Plan in Brussels produced an institutional reaction. In response to the numerous complaints and petitions, the European Commission initiated contact with Spain's Ministry of the Environment in order to obtain information to prepare its own position. In October 2000, when the plan was still in draft phase, the European Commission sent a letter to the Spanish government expressing its concern over compliance with Directive 79/409/EEC on the conservation of wild birds, Directive 92/43/EEC on the Conservation of Natural Habitats and Wild Fauna and Flora, and Directive 97/11 amending Directive 85/337/EEC on the Assessment of the Effects of Certain Public and Private Projects on the Environment. The European Commission also provided a reminder about the consequences of noncompliance regarding the co-financing of projects. In July 2001, the European Commission reminded the Spanish government to take the 2000/60/EC WFD into account and recommended that it produce a Strategic Impact Assessment pursuant to the 2001/42/EC Directive. In response to EU pressure, in January 2002, following adoption of the National Water Plan, the government sent a Strategic Impact Assessment to the European Commission. Further technical dialogue took place between the Commission and the Ministry of the Environment until 2004. That year, the European DirectorateGeneral for the Environment issued a report expressing doubts about the viability of the plan, its environmental impact, and its eligibility to receive Cohesion Fund money.

At the domestic level, a wide range of social organizations created a territory-based network, above all in the Ebro Delta and the Mediterranean regions. Their main initiatives included active involvement in the National Water Council, whose opinion was required before parliamentary adoption of the plan. The groups themselves also issued opinions and allegations and sent them to members of parliament and political parties, and condemned the expected consequences of the plan in the media. Those with an ad hoc focus managed to mobilize extensive resources. The organization COAGRET was a case in point. It embraces representatives of the affected municipalities, social organizations, and the scientific community as well as individuals and opinion leaders. One of its members, the Association for the Defense of the Ebro River, was particularly vigorous in activating political, cognitive, and social resources against the adoption of the plan. Counting on the support of the association, COAGRET organized a wide range of entrepreneurial initiatives, including publication of manifestos, participation in workshops and seminars, and organization of massive demonstrations. Social organizations also succeeded in maintaining constant media attention, both before and after the adoption of the plan. Significantly enough, in 2001, COAGRET, the Association for the Defense of the Ebro River, SEO/BirdLife, and representatives of many other social organizations participated in the so-called Blue March to Brussels, where they lodged complaints about the National Water Plan to the European Commission and the European Parliament. The march received continuous media coverage.

Needless to say, the production of science-based information was a crucial aspect of social actors' entrepreneurial strategy. They were very active in both technically assessing the social, environmental, and economic consequences of the National Water 
Plan and in proposing policy alternatives. These organizations behaved proactively in mustering knowledge-based resources. WWF-Spain, for instance, produced an environmental assessment of the impacts of the projected dams and water transfers that were affecting nature sites contained in Natura 2000. At the EU level, the main environmental players and the New Water Culture Foundation participated in the technical meeting hosted by the European Commission in October 2003, which was also attended by representatives of Spain's Ministry of the Environment and the Brussels representative of the Aragon region. The meeting addressed two technical questions: the projected future water flow in the Ebro River, and the flow regime in the lower Ebro required to ensure the protection of the ecological and chemical status of the river and its delta (European Commission 2009).

The scientific community was also actively involved at different stages of the policy process. The Ministry of the Environment commissioned about 100 studies, some of which were favorable and others that were unfavorable to the National Hydrological Plan. Among the latter were the technical reports issued by the New Water Culture Foundation, which were vital in introducing changes in the dominant governance paradigm. The Foundation was created in 1998 with the aim of stimulating a multidisciplinary debate on water and sustainability. Every two years since then, the Foundation has organized the Iberian Congress for Water Management and Planning, which brings together representatives of the scientific community with the support of more than 70 universities (New Water Culture Foundation 2010)). In addition, the Foundation has organized various conferences and workshops, published articles and reports, and organized other related activities. The proactive involvement of the New Water Culture Foundation has contributed greatly to the questioning of core policy beliefs and the promotion of alternative ideas on water management. In this respect, it is worth mentioning the leading role played by the president of the New Water Culture Foundation, Pedro Arrojo, a professor of economics at the University of Zaragoza. With the support of the Foundation as well as a wide range of social and environmental organizations, he produced a diverse set of scientific studies that questioned the 2001 National Hydrological Plan. He also gave advice to the European Commission on the Plan, including a strategic impact assessment and a socio-economic assessment of the transfer projects included in the Plan. He was one of the leading voices against the institutionalized problem-solving approach as he sought out the most favorable venues for transforming the dominant policy image.

Together with social actors and the scientific community, a few regional administrations, in particular Aragon and Catalonia, have also employed several types of entrepreneurial strategies. Since the early 1990s, the Aragon administration has unremittingly led the territorial opposition to policy initiatives based on water diversions. More recently, the Catalan Water Agency has launched a broad process of participation and consultation in order to comply with the stipulations contained in the WFD. Increasing debates on water policies have involved representatives of the Catalan government, industrial users, energy users, urban supply users, irrigation users, users for leisure and recreational purposes, environmentalists and ecological associations, universities and research centers, trade unions, and other social movements, including residents and cultural associations (Parés et al. 2009). Within this process, the agency commissioned the New Water Culture Foundation in 2004 to draw up a strategy for water management that incorporated the philosophy of the WFD. The resulting study has served as an input for the Catalan agency to formulate its water management strategy.

Contrary to social organizations, the scientific community, and certain regional administrations, the Socialist Party has exhibited less persistency in its entrepreneurial activity. Its role as a policy entrepreneur has been somewhat discontinuous since the early 1990s. During this period, it shifted its position on water policy from a traditional approach, as adopted in the so-called "Borrell Plan", to an alternative supply-based approach in 2004, but it seems to have reconsidered the model since 2008. In the first stage of the transition period, the Socialist Party faced poor internal cohesion around the longstanding distributive problem of water. At one extreme, the regional President of Aragon actively opposed the Plan and the Ebro transfer by arguing that they would have negative social, economic, and environmental consequences for the region, which was one of the least developed areas in the country. At the other extreme, the long-standing regional presidents of the Extremadura and Castilla-La Mancha, Juan Carlos Rodríguez Ibarra and José Bono, supported the National Water Plan in 2001 
in order to protect territorial interests. They changed their position only when the Socialist Party produced an alternative plan (Conejero Paz 2005). At that point, the Socialist Party plan included the construction of a large number of desalinization plants and the elaboration of an irrigation plan, among other features (Conejero Paz 2005). Since then, with a more coherent position, the Socialist Party promised to cancel the National Water Plan. Indeed, the reversal of the National Water Plan was one of the most outstanding electoral promises by the socialist candidate at the 2004 elections, José Luís Rodríguez Zapatero. Following the Socialist Party's victory, President Rodríguez Zapatero demonstrated his commitment to alternative schemes of water policy by means of appointing Cristina Narbona to head the Ministry of the Environment. Narbona had long held the respect of the environmental community and was deeply committed to amending the 2001 National Water Plan. Undoubtedly, the change of government resulting from the political scenario that arose from the 2004 elections opened a political opportunity window for the socialist president to put forward an alternative policy option.

Despite symptoms of change, however, policy entrepreneurs have not demonstrated sufficient capacities to significantly advance the completion of water transition. The policy changes introduced following the 2004 elections failed partially after the Socialist Party renewed its mandate in the 2008 elections. When the Ministry of the Environment was subsumed into the Ministry of Agriculture, alternative schemes of water policy based on the desalinization and on water pricing principles deflected policy attention while the debate on interbasin water transfers does not appear to have been completely eliminated from the agenda (Weyndling 2009). In Catalonia, despite change prospects, the regional government is subject to intense pressure from some political parties, industry, and engineers' organizations that are advocating for transfers from distant rivers in order to deal with the draught problem. Within this context, the Catalan administration does not appear to completely discard intra-basin water interconnections. Overall, these developments both at the national and regional levels indicate that the water agenda is discontinuous and suggest that the path of policy change is anything but straightforward.

\section{DISCUSSION}

Policy entrepreneurs have been particularly active in influencing and connecting the water problem and policy streams in order to challenge the traditional water agenda and influence water policy in more sustainable terms. Throughout the transition period, they were persistent in attaining recognition that the traditional supply-based approach to water management is unsustainable, and they managed to put forward alternative ideas on water management by employing a wide range of strategies. During the first stage of the transition, policy entrepreneurs mostly mobilized their resources to influence the problem stream process. Intense public debate enhanced by policy experts, researchers, economists, environmentalists, and other social groups led for the first time to the suppression of a drafted water plan, which was heavily based on supply intervention principles. During the second stage, policy entrepreneurs were increasingly active in influencing and connecting the problem and the policy streams which, in both processes, came as a reaction to the national water plan of 2001. Their challenge to the dominant agenda was linked to their leading role in formulating knowledge-based policy alternatives and providing them with visibility and credibility. In a context of escalating confrontation between policy entrepreneurs of change and policy opponents to change, changes in the politics stream opened up a window for policy entrepreneurs in at least two ways. Firstly, government turnover following the 2004 elections altered the politics stream. And secondly, the need to comply with the requirements of the WFD enhanced policy entrepreneurs' position vis-à-vis change opponents. This opportunity facilitated the redefinition of the water policy agenda towards alternative supplymode types of intervention mostly based on desalinization. Despite the adoption of alternative solutions, the government's approach to water management, has on a whole, been discontinuous as water transfer solutions to scarcity problems have recently shown up in the policy debates.

Which strategies have been employed by policy entrepreneurs to challenge the traditional agenda? In line with the theoretical assumptions included in the introductory article of this special feature, four types of interrelated entrepreneurial strategies are most notable. First and foremost, policy entrepreneurs have played an active role in developing and selling alternative water policy ideas that are robustly grounded in scientific 
research (Huitema and Meijerink 2010). Policy entrepreneurs' persistence in conducting research tasks, spreading alternative ideas and knowledge, and maintaining media attention has been central in putting forward alternative policy ideas. Notably, the leadership and leading capacities of the New Water Culture Foundation to produce knowledge, enhance shared beliefs, pool resources, and provide policy options, for instance to the Catalan administration, must be emphasized. Secondly, policy entrepreneurs have created joint networks and succeeded in building multi-actor and multilayered coalitions that comprise a wide range of social organizations, large sectors of the scientific community, and a few regional administrations, which have had less abiding support from some political parties. Thirdly, policy entrepreneurs have been relatively successful in exploiting the political opportunity window that has stemmed from the combination of the increased attention paid to the issue on the political agenda, the policy-makers' concern over water management options, and the political scenario in the aftermath of the 2004 elections. And finally, policy entrepreneurs have been able to shop among multiple institutional venues as a way of amplifying their concerns and finding institutional alliances. Significantly enough, the EU has provided new venues, namely the complaints system and the WFD requirements, which are regularly used by policy entrepreneurs in the water sector.

Overall, policy entrepreneurs have performed differently throughout the transition period. Variations in policy entrepreneurs' commitment to policy change and persistence have been observed. Social organizations that encompass environmental groups and different types of social movements were among those that performed their entrepreneurial role more persistently and showed deepest concern about policy change, with the New Water Culture Foundation and the Association for the Defense of the Ebro River as outstanding examples. The Socialist Party, by contrast, has exhibited a discontinuous commitment with alternative options to water management, especially since the desalinization solution has undergone criticism by both the environmental and the agriculture sectors. With regards to regional administrations, the Catalan Water Agency has demonstrated increasing concerns about the stipulations contained in the WFD.

\section{CONCLUSIONS}

Water management is perhaps one of the most critical issues in Spain. The combination of historically cyclical droughts and a rapid increase in the number and types of water uses in recent decades makes water policy a focal point of public intervention and a subject of political, socioeconomic, and territorial controversy. In addition, the geographical and climatic diversity of the territory, in which a wet northwest and a dry southeast Spain co-exist, has accentuated the distributive conflict. Who has the right to use water, who bears the environmental costs, and who pays for the real cost of water are just some of the core issues at stake. In recent years, new considerations have been introduced into the water policy agenda, some of which emphasize sustainability and efficiency. Yet, the prevalence of conflicting views on how to meet both of these guiding principles in dealing with the water scarcity has prevented the introduction of far-reaching changes in water management. The institutionalized policy image of water management based on the promotion of statesubsidized large-scale supply infrastructure has been prevalent, following long-standing traditions that date back to the 1950s and earlier. Water management in the last two decades has inherited some of the problem-solving approaches of the past. However, some signals of transition towards a relatively more sustainable management model have gradually emerged. Deviations from the traditional path consist of the gradual combination of the traditional approach with alternative regulations on supply.

For obvious reasons it is too early to assess the outcomes of changes in the approach to water policy that were introduced in recent years. During the twodecade period analyzed, the policy agenda has incorporated the sustainability rhetoric, and national and some regional administrations have attempted to experiment with alternative approaches to large inter-basin transfers to resolve the problem of water scarcity. Nevertheless, these policy changes may not necessarily involve a long-term fundamental change. As recent events show, old ideas about water management that rely on supplyside and inter-basin water transfers have not completely disappeared. Such developments raise two core questions. Firstly, they suggest the idea of agenda discontinuity. Water transition is a rather discontinuous and irregular process with alternative policy ideas and options going back and forward in 
the agenda. As the Spanish situation shows, some symptoms of change are clearly noticeable, although water transition is far from being completed. And secondly, this incompleteness raises the question of the extent to which policy entrepreneurs have succeeded in their transformational aims. Here, their role as advocates of policy change can be understood only by looking at their strategies from a long-term perspective. This article has demonstrated that policy entrepreneurs' capacity to challenge a deep-rooted policy image that associated the dam approach with the idea of progress and territorial solidarity cannot be disregarded. While water transition seems far from being completed, policy entrepreneurs have managed to open new avenues for policy change.

Responses to this article can be read online at: http://www.ecologyandsociety.org/voll5/iss2/art25/ responses/

\section{Acknowledgments:}

Ecology and Society wish to thank the authors and Edward Elgar Publishing who have kindly given permission for the use of material from D. Huitema and S. Meijerink, editors. 2009. Water policy entrepreneurs: a research companion to water transitions around the globe. Edward Elgar Publishing, Cheltenham, UK.

\section{LITERATURE CITED}

Bakker, K. 2002. From state to market?: Water mercantilization in Spain. Environment and Planning A 34(5):767-790.

Baumgartner, F. R., and B. D. Jones, editors. 2002. Policy dynamics. University of Chicago Press, Chicago, Illinois, USA.

Bukowski, J. 2007. Spanish water policy and the NHP: an advocacy coalition approach to policy change. South European Society and Politics 12 (1):39-57.

Conejero Paz, E. 2005. El Plan Hidrológico Nacional. Un enfoque neopluralista, Proceedings of the VII Congreso Español de Ciencia Politica, 21-
23 September 2005, Madrid, Spain. [online] URL: http://www.aecpa.es/archivos/congresos/congreso 07/ area03/GT08/CONEJERO-PAZ-Enrique(UHM).pdf

Costejà, M., N. Font, and J. Subirats. 2004. The evolution of water regime in Spain. Pages 235-263 in I. Kissling-Näf and S. Kuks, editors. The evolution of national water regimes in Europe. Transitions in water rights and water policies. Kluwer Academic Publishers, Dordrecht, The Netherlands.

Di Stefano, L., and G. Schmidt. 2005. Los bancos de agua: una oportunidad para los ríos y la gestión de sequías. Ambienta 72. [online] URL: http://www .mma.es/secciones/biblioteca publicacion/publicaciones/ revista ambienta/n45/pdf/72 wwfadena45.pdf.

Downward, S. R., and R. Taylor. 2007. An assessment of Spain's Programa AGUA and its implications for sustainable water management in the province of Almería, southeast Spain. Journal of Environmental Management 82(2):277-289.

Espluga, J. L., and J. Subirats. 2007. Participación ciudadana en las políticas de agua en España. Fundacion Nueva Cultura del Agua, Sevilla. [online] URL: http://www.unizar.es/fnca/v arios/panel/53.pdf.

Esteban, A., and N. Prat, editors. 2006. Alternativas para la gestión del agua en Cataluña. Una visión desde la perspectiva de la nueva cultura del agua. Bakeaz/FNCA, Zaragoza, Spain.

European Commission. 2009. [online] URL: http: //ec.europa.eu/environment/water/spanish hydrolo gical plan.html.

Huitema, D., and S. Meijerink. 2010. Realizing water transitions: the role of policy entrepreneurs in water policy change. Ecology and Society 15(2): 26. [online] URL: http://www.ecologyandsociety.org/vol15/ iss $2 / \operatorname{art} 26 /$.

Kingdon, J. W. 1995. Agendas, alternatives and public policies. Harper Collins, New York, New York, USA.

Ministerio de Medio Ambiente. 2005. Programa AGUA. Actuaciones para la gestión y la utilización del agua. [online] URL: http://www.mma.es/seccio nes/agua/entrada.htm. 
New Water Culture Foundation. 2010. [online] URL: http://www.unizar.es/fnca.

North, D. 1990. Institutions, institutional change and economic performance. Cambridge University Press, Cambridge, UK.

Parès, M., B. Gener, H. Cruz, and M. Martí. 2009. La participació ciutadana en la gestió de l'aigua. Escola d'Administració Pública de Catalunya, Barcelona, Spain.

Pierson, P. 2000. Increasing returns, path dependence, and the study of politics. American Political Science Review 94(2):251-267.

Saurí, D., and L. del Moral. 2001. Recent developments in Spanish water policy. Alternatives and conflicts at the end of the hydraulic age. Geoforum 32(3):351-362.

Tàbara, J. D., and A. Ilhan. 2008. Culture as a trigger for sustainability transition in the water domain. Regional Environmental Change 8(2):5971 .

Thelen, K. 1999. Historical institutionalism in comparative politics. Annual Review of Political Science 2:369-404.

Water Act. 1985. Ley 29/1985, de 2 de agosto, de Aguas. Government of Spain.

Weyndling, R. 2009. Spanish water policy: a hostage to politics. ENDS Europe, 20 May 2009.

World Wildlife Fund for Nature (WWF)-Spain. 2007. [online] URL: http://www.wwf.es/noticias/sa la de prensa/?1542. 